NBER WORKING PAPER SERIES

\title{
COMMITTEE STRUCTURE AND THE SUCCESS OF CONNECTED LENDING IN NINETEENTH CENTURY NEW ENGLAND BANKS
}

\author{
Christopher M. Meissner \\ Working Paper 9792 \\ http://www.nber.org/papers/w9792
NATIONAL BUREAU OF ECONOMIC RESEARCH 1050 Massachusetts Avenue Cambridge, MA 02138
June 2003

I would like to acknowledge helpful support, comments and discussion from Howard Bodenhorn, J. Bradford DeLong, Barry Eichengreen, Richard Grossman, Rupert Gatti, Tim Guinnane, Eric Hilt, Naomi Lamoreaux, Tim Leunig, Christina Romer, Jean-Laurent Rosenthal, Peter Temin, Oliver Williamson and seminar participants at UC Davis, the ASSA Clio session 2003, London School of Economics, Newcastle, Oxford and UC Berkeley. The Baker Library historical collections staff and the Bank Boston research consultants graciously assisted the historical research. Financial support from the Alfred D. Chandler Jr. Traveling Fellowship from the Harvard Business School and a grant from the Institute of Business and Economic Research (IBER) at U.C. Berkeley made this paper possible. All remaining errors are my own. The views expressed herein are those of the authors and not necessarily those of the National Bureau of Economic Research.

(C)2003 by Christopher M. Meissner. All rights reserved. Short sections of text not to exceed two paragraphs, may be quoted without explicit permission provided that full credit including $\mathbb{C}$ notice, is given to the source. 
Committee Structure and the Success of Connected Lending in Nineteenth Century New England Banks

Christopher M. Meissner

NBER Working Paper No. 9792

June 2003

JEL No. D71, D72, G3, N2, N8

\begin{abstract}
Early nineteenth century New England banking exhibited high levels of lending to directors and their associates (i.e., connected lending). Today many think this arrangement can lead to inefficiency and financial fragility. This paper explores the decision making processes inside these banks and argues that connected lending was viable when many people were involved in loan decisions. The committees used to vote on the approval of loans are the focus. Banks that required more votes for a given committee size prevented the approval of loans with private gains and social costs. The historical data are consistent with the idea that higher levels of consensus in the loan committees raised the return on assets.
\end{abstract}

Christopher M. Meissner

University of Cambridge

Faculty of Economics \& Politics

Austin Robinson Building

Sidgwick Avenue

Cambridge CB3 9DD ENGLAND

and NBER

cm331@cam.ac.uk 


\section{Introduction}

Banks are thought to have contributed to the Asian financial crisis of the late 1990s. Observers noted they were loaning heavily to "insiders" and close connections. ${ }^{1}$ These firms were alleged vehicles for "crony capitalism."

Such patterns are not new. Lamoreaux (1994) and Beveridge (1985) provide evidence for the high incidence of insider lending in early nineteenth century New England banks. Lamoreaux forcefully argued that reputation, among other factors, ensured that New England banks chose good projects despite the possibility of producing an outcome similar to Suharto's Indonesia.

This paper takes a close look at the decision making procedures of these nineteenth century banks. It follows up on the observation by Lamoreaux that these mechanisms might have complemented other factors to bring about good lending practice and compares a simple model with the data. When banks included many people in the decision to lend, "insider" or connected lending was less likely to be troublesome.

Specifically I show how certain voting rules helped limit the poor project choice unfettered connected lending may have generated. Banks that required more votes to approve a loan were less likely to approve bad projects involving personal gains and social costs. Including more voters in the decision internalized the negative externalities associated with bad projects. I also analyze the choice of the voting rule. In the model, banks face a trade-off between better project choice and higher costs associated with reaching a consensus. For a given number of directors, higher levels of consensus are chosen when the costs of reaching a consensus are lower.

Data from 26 banks operating in the northeastern U.S. between 1784 and 1862 are presented to support the analysis. Of these banks, 35 percent explicitly used a voting

\footnotetext{
${ }^{1}$ By connected lending or insider lending, I mean the extension of loans to bank directors and principal shareholders (insiders) or close associates and family (connections). The Bank Negara Indonesia allegedly practiced such lending. According to the Financial Times (Dec. 1, 1999) the listed, state bank extended nearly $\$ 1.3$ billion in loans (more than four times the bank's capital) to a textile firm run by close connections of ex-president Suharto. The mostly bad loans and the debtors were out of reach of the Indonesian financial restructuring company as of that date.
} 
mechanism to approve loans; 25 percent used an executive decision maker to approve loans. I use this information, along with balance sheet data on a set of Boston banks, to show that the data are consistent with the theoretical model.

Banks with higher levels of consensus raised their return on assets. Each additional vote required to approve a loan is associated with a two and a half percent increase in the return on assets. Likewise, evidence from regressions suggests that using a "two votes enough to reject" decision rule may have raised this ratio by around 50 percent relative to banks that did not formally state their loan decision rule. The econometric results are fairly robust to alternative specifications, and they corroborate anecdotal evidence.

This paper begins by documenting the salient features of early nineteenth century New England banking. ${ }^{2}$ The next section illustrates more formally the role discount committees played in early American banking. I proceed to an analysis of the archival records of the banks. Section 5 explores the empirical relation between consensus size and the return on assets. I then examine the varying success other incentives and regulations had in maintaining a well-functioning banking system. I conclude by noting some ways in which these mechanisms of control were beneficial to the stability and efficiency of early American capital markets and economic growth.

\section{A Brief Outline of Early New England Banking}

In the wake of the American Revolution, financial markets in the US burgeoned. Prior to 1782, when the first public American bank (the Bank of North America) was chartered, financial intermediation occurred through private lenders. Borrowers from private banks were allegedly charged exorbitant rates of interest; financial intermediaries were scarce. The appearance of the Bank of North America and the Massachusetts Bank in Boston in 1782 and The Bank of New York in 1784 brought forth a new model of American banking

\footnotetext{
${ }^{2}$ On the general history of New England banking see Lamoreaux (1994), Knox (1900) and Felt (1839). Lamoreaux (1994) and Gras (1937) mention these rules in the context of particular banks, and both conjecture that the mechanisms worked as described above. This study collects some systematic data on the prevalence of these institutions and their evolution over time. It also contributes an empirical examination which shows how much these rules mattered.
} 
that would persist for over 80 years and presaged an explosion of publicly chartered commercial banks.

These banks often resembled familial clubs especially in the smaller states of New England. Beveridge (1985) and Lamoreaux (1994) describe the typical pattern of banking. A number of businessmen from the local community would apply to the state government for a charter to become a note issuing institution. Capital was paid in to a certain level before operations could start. The founders, who would often become the managing directors of the banks, along with insurance companies, savings banks and many other individuals purchased the bank capital. ${ }^{3}$

Banks of the era took deposits but rarely counted on these funds as reserves against liabilities (Hammond, 1957; Lamoreaux, 1994). Neither did banks create too many deposits in the course of business as modern banks might. ${ }^{4}$ The absence of depositors, who might serve as monitors over banking practices, meant that other means must have been necessary to watch over bank lending practice.

Banks "discounted" commercial paper but also granted loans in the form of "accommodation" paper. These were usually set to have a short-term maturity of 45 to 90 days. However they were often renewed several times so that the borrowers could make investments or improve land. This made for many de facto long-term loans.

These early banks frequently relied on "insider lending” (Lamoreaux, 1994; Beveridge, 1985). ${ }^{5}$ Banks disproportionately issued loans to directors, founders, business associates, and family. Such transactions made the banks vehicles for the personal enrichment of directors and friends. Commentators in the Northeast worried about the favoritism

\footnotetext{
${ }^{3}$ Lamoreaux reports that the ownership of equity in banks was not too concentrated among directors and their connections. Outsiders like widows, insurance companies, and savings banks also held a large amount of stock. In Maine in 1840 the average percentage of stock held by managers and individuals with the same last name was 35 (Lamoreaux, 1994 p.71). In Boston the number was 11 percent in 1867 (Lamoreaux, 1994 p.72).

${ }^{4}$ In fact deposits were actively discouraged. Many commercial banks initially charged interest on funds deposited at the bank! Banks rescinded this policy as the banking industry became more competitive and deposits eventually became more common. The Suffolk System did provide some monitoring however.

${ }^{5}$ Beverdige (1985) reports that between 1833 and 1897 nearly $39 \%$ of local lending of the Cheshire Provident Institution for Savings in New Hampshire was classifiable as connected lending. Lamoreaux presents similar evidence for the entire New England region in the same period.
} 
rampant insider lending entailed. ${ }^{6}$ But Lamoreaux (1994) argues this type of lending increased the efficiency of local financial markets by attenuating the information problems inherent to such transactions. Directors had better information about their projects and their families' projects. This allowed them to overcome adverse selection problems. ${ }^{7}$ Furthermore, bankers showed judicious restraint. Bankers wanted to maintain a reputation in the community because they depended on outside capital. This prevented loans made strictly for personal gain or non-economic reasons. It also inhibited fraudulent defaults.

Outside investors in the banks knew how their money would be invested because they perceived the loans were mainly going to the directors. ${ }^{8}$ People in the small communities of early nineteenth century New England were familiar with the directors of banks and their businesses. The reputational mechanism and the information available partially allowed outside investors to adequately judge the risks of the banks and to make the appropriate decision about equity participation in the bank.

In contrast to current thinking, contemporaries argued that entrusting funds to insiders would lead to over-extended note issues and imprudent lending (Defence of the Country Banks). Bankers had incentives to invest in projects with private gains and social costs. They would prefer to allocate funds to projects in which they, their family or their associates had a personal interest. Losing would mean little when in control of others' money, but individuals would reap the benefits from winning and also garner a private benefit from having such easy access to capital.

Commentators on the Canadian banking system in the late nineteenth century keenly observed these same problems. In Canada, as in New England, directors who had personal business interests made the daily decisions on loan allocations. Not surprisingly they

\footnotetext{
${ }^{6}$ A contemporary example is the anonymous A Defence of the Country Banks Being a Reply to a Pamphlet Entitled An Examination of the Banking system of Massachusetts in Reference to the Renewal of the Bank Charters.

${ }^{7}$ Moreover, if insiders were large shareholders themselves they would have an incentive to prudently allocate loans as long as the immediate private gains from mis-management were not too high. In any case, directors do not seem to have been major shareholders at all times.

${ }^{8}$ In addition, shareholders did have the right to control directors' actions but rarely did (Lamoreaux, 1994). Small shareholders were also protected from large shareholders by rules limiting their voting power. However, any action stockholders could take would be ex post and may have been too late.
} 
apparently received a great proportion of the loans. The History of Banking in all the Leading Nations (1896) cited a fundamental trade-off in this type of transaction by noting:

If a bank has directors who do not borrow, it runs great risk of not being in touch with the business community. On the other hand, as long as directors are allowed to borrow from the bank at whose board they have a seat, there will be losses, and occasionally, losses not justifiable.

Given the incentive difficulties in maintaining the integrity of such a transaction, what forces created trust in bankers' choices? Reputations and community linkages were surely useful. Nevertheless, specific institutional arrangements could also help make sure that only socially optimal projects were implemented.

\section{The Function of Discount Committees}

Once chartered and capitalized, banks in New England often proceeded to issue loans to themselves, their associates and their family members. Bankers frequently managed to invest their funds both prudently and profitably. Lamoreaux (1994) notes that the banks often earned returns equal to or greater than those on municipal bonds. Bank failures were relatively rare at the time. However, the directors had great interest, or on average faced little immediate sanction by taking loans that would be personally beneficial and potentially unsound from an economic point of view. How could banks avoid this temptation? The answer partially lies in the day-to-day decision making procedures for allocating loans.

In practice banks had an array of ways to organize the loan approval process. Examples included delegating the decision to one director, having a small standing committee or a large committee including all directors. ${ }^{9}$ The size of the necessary majority to ap-

\footnotetext{
${ }^{9}$ By committee I mean an organization with $N$ members. Each member must vote or decide on whether to approve a project. A simultaneous consensus of size $K \leq N$ is necessary to approve a decision.
} 
prove a loan within the committee also varied across banks and over time within banks.

Intuitively, placing one director in charge of loan decisions could have led to excessive lending. Supposing this director would have a private gain from allocating a loan, any potential losses would be sustained by other stakeholders in the bank. But these would not be considered in the decision process of such an organizational form because the potential losers had no say in the decision. When it would be difficult ex post to ascribe the cause of failure to injudicious decision making, ascertaining the culpability of the director for making a bad decision could be difficult.

Banks did have a chance to prevent too much illicit behavior before any loans were allocated by creating a monitoring mechanism that could oversee the loan approval process and rule out the worst loans from the social point of view. Inspection of the banks' minutes and bye-laws suggests that directors sometimes did just that. Implementing a committee of directors which had to vote to approve a proposed loan may have prevented the most inefficient allocations. Certain rules requiring large majorities made it more costly for the bank's decision-makers to approve an unsound project.

Nevertheless it is likely that the directors had to balance the social losses against the costs of these monitoring mechanisms. Including more members on the committee made the decision making process more time consuming, and approving a loan became costlier. Moreover, and most crucially, for a given committee size it is likely that higher consensus rules were also more costly. High consensus rules might have caused delays. Winning coalitions had to be generated. More people had to be convinced to approve a loan. Time spent doing this could have been devoted to other activities.

Section 3.1 sets up a stylized model of banking committees. It shows that the larger the number of votes needed to approve the loan of an insider, the less prone a bank was to perfidious collusion (i.e., to approve a low-quality loan that was socially undesirable). The intuition for this is fairly straightforward. Suppose the consensus was small, and a director with a socially costly project applied for a loan. If the director had to garner the support of one other person, then he might promise this other voter a percentage of 
the expected private proceeds from the inefficient project. The colleague would approve as the private loss from accepting may be small (i.e., the bank in which the director has a direct interest may be slightly less profitable). But the expected private gains may be larger and hence he could be compensated.

On the other hand, a committee with a large consensus would not be prone to such collusion. In this case the private gain to any one voter on the committee from accepting decreases with the number of committee members the director must convince. However, the private loss stays the same as in the situation where fewer votes are needed. Larger discount committees with a larger consensus necessary to approve a loan are likely to have eliminated projects with the highest social costs. Hence they are also likely to have generated better bank performance.

Larger levels of consensus ruled out a greater proportion of a bank's possible projects. This "prudent" or conservative practice is how the Massachusetts Bank claimed it was conducting business in the late eighteenth century. At the time, it was using a "two votes enough to reject rule" with a large committee of twelve people.

\subsection{A Model of Collusion and Discount Committees}

In what follows, I present a simple formal model to show how committee structure can internalize the externalities involved in a group decision. Committees vote on whether to approve a loan or not and members may collude prior to voting. Large majorities make it difficult to "bribe" the necessary amount of committee members to pass a low-quality proposal. A bank that includes more people in the decision regarding loans can avoid losses and earn higher profits.

The structure of the model is as follows. Banks come into existence and are governed by $N$ directors. Banks set up a committee voting rule to maximize each director's ex ante expected utility. The rule requires $K$ votes out of $N$ to approve a loan. The bank takes into account private incentives and the costs of each type of rule. After a committee rule is chosen, nature chooses one of the directors to propose a project. Each director is 
identical and can choose from an array of projects which vary in terms of the net private benefits available. Projects are indexed by a success probability: $\pi \in[\underline{\pi}, 1]$. After a project is chosen, the approval of the committee is sought. As presented, there is no asymmetric information amongst the players. The decision makers are insiders or are connected. ${ }^{10}$ Collusion amongst the directors can occur, so approval can be bought with "bribes" of size $\tau$ if necessary. If a loan is approved, the borrower takes the loan and then pays back the full ex post return from the loan. An equilibrium specifies a project, $\pi$, the size of the bribes, $\tau$, the size of the consensus level, $K$, and the votes for each of the committee members, $s$. It is denoted by: $(\pi, \tau, K, s)$.

To facilitate analysis, I will start by analyzing the optimal project choice for the chosen director and a given committee rule. Each project, $\pi$, brings a personal benefit $\gamma(\pi)$. I assume that $\gamma^{\prime}>0$ and $\gamma^{\prime \prime}<0$. Projects yield some expected return with a probability $\pi$ and nothing otherwise. The expected return from a project, and the amount the bank can collect from an agent is given by $E(\pi) \equiv \pi \phi(\pi)$. Let $E^{\prime}(\pi)>0$ so that projects with higher expected returns are safer.

When a project is proposed, each member of the loan committee evaluates whether to approve or not on the basis of the expected returns. I also assume that if a project is rejected that an alternative outside return can be earned that is equal to the expected return from taking the highest project which is denoted as $\phi(1)$. Assume also that $\gamma(\underline{\pi})>\underline{\pi} \phi(\underline{\pi}), \gamma^{\prime}(\underline{\pi})>E^{\prime}(\underline{\pi}), \gamma^{\prime \prime}<E^{\prime \prime}(1-\alpha(K-1))$ and $\gamma(1)<\phi(1)$. These conditions make it so that it is optimal for an individual director to take a project that is between $\underline{\pi}$ and 1 .

Each director, as a shareholder in the bank, has a right to a share of the profits $\alpha<\frac{1}{N}$ in the form of dividends and/or a salary. For simplicity I assume all directors are identical. Hence the $N$ directors own less than all of the bank. In order to approve a loan, each decision maker on the committee must earn at least as much as he could in the alternative investment which is $\alpha \phi(1)$. Directors proposing a loan can always find

\footnotetext{
${ }^{10}$ The model could incorporate asymmetric information about the quality of loans but would complicate the analysis slightly. However, it is unlikely that the main results would be changed.
} 
a project that yields positive private surplus, so to achieve support for the project from the committee, $K-1$ votes must be garnered. The votes can be won by promising a proportion of the private surplus available to a proposer which I call $\tau(\pi)$.

I also assume that higher levels of consensus for a fixed committee size entail higher costs to each director. This could be due to the greater amount of time spent by directors involved in forming a coalition. For example directors will have to spend time liasing with the proposer and vice versa. I model the costs of committees and consensus as a general cost function, $c(K, N)$, which is weakly separable in $K$ and $N$. Also let $\frac{\partial c(K, N)}{\partial K}>0$ and $\frac{\partial^{2} c(K, N)}{\partial K^{2}}>0$ and likewise for $N .^{11}$

Two comments are in order. First the costs of consensus are incurred no matter which project is chosen, even if it is the outside option. These costs do not have to be compensated by the proposer. Second it follows that the optimal individual project choice does not depend on the size of $K$ when the optimal project does not involve a binding individual rationality constraint.

With this information, we now see that a director chosen to propose a project would choose the project $\pi$ to maximize his utility subject to the constraint that the utility from taking a project is at least as large as that from the outside option which has a return of $\alpha \phi(1)$. The director then solves the following problem:

$$
\begin{gathered}
\max _{\pi} E(U(\pi, K))=\gamma(\pi)-(1-\alpha) \pi \phi(\pi)-(K-1) \tau(\pi)-c(K, N) \\
\text { s.t. } E(U(\pi, K)) \geqslant \alpha \phi(1)
\end{gathered}
$$

In equilibrium the appendix shows that the bribe $\tau(\pi)$ is equal for all $K-1$ votes and is equal to $[\alpha \phi(1)-\pi \phi(\pi)]$. This level of a transfer makes voters indifferent between approving and not approving. The appendix also shows that the optimal project can be

\footnotetext{
${ }^{11}$ The cost arising from $N$ is the opportunity cost of attending loan committee meetings.
} 
implemented as a Nash equilibrium of the voting game. The next question is which $\pi$ is chosen as a function of $K$ ?

Assuming that the individual rationality constraint is not binding, the first order condition, which implicitly defines an optimal project is

$$
\gamma^{\prime}(\pi)-E^{\prime}(\pi)[1-\alpha(K-1)]=0
$$

For the well-behaved smooth functions assumed here, the solution is unique and depends positively on the level of consensus $K$. Defining $\pi^{*}(K)$ as the optimal project for a given $K$, using the fact that the optimal project must satisfy $\frac{\partial U(\pi(K), K)}{\partial \pi}=0$ and totally differentiating both sides of $(2)$ yields $\frac{d \pi^{*}}{d K}=\frac{-\alpha E^{\prime}}{\gamma^{\prime \prime}-E^{\prime \prime}[1-\alpha(K-1)]}>0$.

It is also worth noting that as $\alpha$ increases project choice improves. This is intuitive because as the directors own more of the bank they care more and more about the total social return rather than just the private return.

\subsection{Choosing the Optimal $K$}

In the first stage of action, the bank must decide which level of consensus to implement. ${ }^{12}$ If consensus were costless, the bank would like to make the consensus level for a fixed number of directors equal to the number of directors. This is equivalent to setting a unanimous decision rule. This is because such a rule totally eliminates the "externalities" imposed on the losing coalition. However, when consensus size is costly, it can be efficient to incur some of these "externalities" rather than remove them.

The problem the bank faces before any loan comes to the table is to choose a committee structure that maximizes directors' ex ante expected utility subject to an individual rationality constraint. ${ }^{13}$ I assume that each director has an even chance of being chosen

\footnotetext{
${ }^{12}$ For the analysis I assume that the number of directors $N$ is fixed exogenously.

${ }^{13}$ I take this as the objective first because it appears that directors often held significant portions of the stock of banks and hence acted as private clubs. The early banks of New England are often portrayed as gentlemen's clubs existing only for their personal gain. Insofar as outsiders had a stake in the bank it does not appear that they helped plan the organizational structure of the bank or even were permitted to know what the structure was because the bye-laws were not publicly available. Finally, as long as
} 
to take a project. This problem is given by

$$
\begin{gathered}
\max _{K} E\left(U\left(\pi^{*}(K), K\right)\right)=\frac{1}{N}\{\gamma(\pi)-(1-\alpha) \pi \phi(\pi)-(K-1) \tau(\pi)\}+ \\
\frac{N-1}{N}\left\{\alpha \pi \phi(\pi)+\frac{K-1}{N-1} \tau(\pi)\right\}-c(K, N)
\end{gathered}
$$

$$
\text { s.t. } E\left[U\left(\pi^{*}(K), K\right)\right] \geqslant \alpha \phi(1)
$$

Again I assume an interior solution. ${ }^{14}$ The first order condition to the maximization problem is given by

$$
\gamma^{\prime}(\pi)-E^{\prime}(\pi)[1-\alpha(N-1)]=N \cdot \frac{\frac{\partial c}{\partial K}}{\frac{\partial \pi}{\partial K}} .
$$

This condition reveals that a bank would optimally implement a consensus level lower than a unanimous rule decision. First note that when $\frac{\partial c}{\partial K}=0$ the optimal level of consensus the bank would like to impose is $N$. This is seen by comparing (2) and (4) when the right hand side of (4) is equal to zero. In such a case, this comparison shows that the bank's optimal project is only implemented when the project proposer faces a $K$ equal to $N$.

Next, note that the project choice that satisfies (4) is lower than that which satisfies it when $\frac{\partial c}{\partial K}=0$ because of the assumption about the second derivatives of $\gamma$ and $E$. Moreover the optimal solution, $\pi^{o}$, to (4) can be implemented in the second stage with a $K<N$. This follows because the optimal project choice by the proposer declines towards $\underline{\pi}$ as the level of consensus falls away from unanimity.

In the analysis the bank typically does not want to implement the highest yielding project because directors take some personal gain from lower quality projects. In addition, the costs of group decision-making push the bank to use decision rules that require the bank did not perform too poorly, outsiders were unlikely to exercise direct control in the bank. The model offers a reservation payoff that can capture this lower bound.

${ }^{14}$ To make this true we must have, at the optimum, $\frac{\gamma(\pi)-\pi \phi(\pi)}{N}-c(K, N)>\alpha \phi(1)$. I also assume the second-order conditions are satisfied. 
less than unanimity and hence to implement low quality projects. The director chosen to take a project capitalizes on this and is more easily able to afford taking a privately beneficial project that would not otherwise be feasible. ${ }^{15}$

Before discussing the empirical evidence, it would be useful to relate the conclusions from above to Lamoreaux's discussion of what made insider lending work. Nothing in the model rules out directors' concern for their reputation. In fact the committee structures discussed could only have strengthened these factors. If a bank had a genuine concern about maintaining its reputation, it could have ensured its reputation by implementing stronger rules. In the model this could happen if the marginal cost for each additional vote that was needed to approve a loan were lower than for a comparable bank that cared less about its reputation. Such a drop in the marginal cost could bring about higher consensus levels and better project choice.

\section{The Prevalence of Discount Committees and Var- ious Structures}

Appendix B presents discount committee structure for 26 banks from 1782 up to 1862. Many banks stated their decision rule was a super-majority. However, only one bank's records showed evidence of a unanimity rule. A popular rule was a single decider or a "Presidential Style". Finally many banks were silent in their bye-laws on the precise regulations governing loan decisions.

One also sees that banks typically had five to twelve people acting as directors. Often the size for a quorum to discount and to transact other business was five. It was not uncommon to see only one director placed in charge of making the discounts for a particular week. Sometimes his decisions would end up being subjected to approval by the entire board, but at times they were not.

While there is variance in the organizational forms of discount committees across space

\footnotetext{
${ }^{15}$ Without putting more structure on the model, it is impossible to derive an explicit solution for the optimal consensus level and the project choice.
} 
and time, there seems to be a limited menu of options from which the banks selected decision-making mechanisms. The bye-laws, rules and regulations of the banks describe these organizational designs. From these records we find many interesting arrangements.

Discount committees usually met two to three times a week at the beginning of a bank's life. As the banks matured, they seem to have accumulated backlogs of discount demands. A solution was to have the discount committee meet more often. However, this was a costly solution because it took an increasing proportion of the directors' time. As a result, some banks abolished the committee mechanism. ${ }^{16}$

Occasionally banks would put a "director of the week" in charge of the discounts. Usually the bye-laws stipulated that such decisions be scrutinized and subjected to final approval at weekly meetings by the whole of the directors. None of the minutes of the directors meetings I analyzed suggested that the decisions of the director of the week were ever overturned. Nevertheless Gras (1937) cites an illustrative episode at the Massachusetts Bank. In 1786 the board decided to leave the discount decision to a single director for the week. Discounts totalled nearly $\$ 46,000$ on this fateful week, while they had been around $\$ 25,000$ during the prior week. The change in policy was not permanent, and decision-making immediately returned to a committee style system.

Another less radical response was to decrease the size of the whole committee. The Massachusetts Bank did this repeatedly. In 1825 it cut the minimum discount committee size from five to three; in 1831 it changed to a two director discount committee, and in 1840 it succumbed to a one-director discount committee.

Discount committees had a wide range of consensus levels to approve of a discount as well. The Boston Bank and the Massachusetts Bank both began their operations requiring a stringent secret ballot for each discount proposed. Directors voted one-byone, depositing a white or a black ball into a hat. At the Massachusetts Bank, if at least

\footnotetext{
${ }^{16}$ By the Postbellum period, banks had begun to professionalize the loan decision. Lamoreaux suggests that deposit volume and leverage ratios increased making banks more prone to runs. Those with insider lending and less transparent loan standards in an increasingly more complex society were likely to face panics by poorly informed depositors who might infer at a moment's notice that such banks were close to winding up.
} 
one black ball appeared in the hat at the end of voting, the discount would be denied. Such a method may have prevented collusion among insiders when the loan was likely to make the bank suffer.

Another popular rule was the "two negatives enough to reject" rule. This arrangement was used until the national banking era by the North American Bank and Trust Company (New York), the Hartford Bank (Connecticut), the Shoe and Leather Dealer's Bank (Boston), the Boston Bank, Bunker Hill (Charleston, Massachusetts) and the Suffolk Bank (Boston). ${ }^{17}$ This type of rule says nothing about the committee size, but archival records show that the typical minimum committee size was four or five directors.

The Middling Interest Bank of Boston was founded in 1836, and never mentioned its discount rules in its bye-laws. Regulators scrutinized the bank in 1837 and found that management had been turned over to the president soon after establishment. The bank excessively discounted commercial paper; insider lending was rampant and unsecured by collateral. The Middling Interest failed four years after it opened.

Notably, there is a divide between the country and city. Five out of seven of the country banks in my sample made no mention of their discount practices while only three of the eleven Boston banks made no mention of these policies. One country bank, the Dedham Bank, implemented a token measure and held that a director should leave the room when a vote was taken regarding a loan for him.

But not all city banks had well-defined rules for discounts. At the Bank of Philadelphia, there was no mention of the discount rules in the bye-laws. This might explain why one of the founding directors was found to be insolvent at death. It appears he was able to take too many loans from the bank while alive. The same sort of problem plagued the Bank of North America (BNA) in Pennsylvania. This bank does not appear to have had a bye-law specifying how loans would be allocated. Robert Morris, one of the BNA's directors and former treasurers was sent to debtor's prison after having made excessive speculative loans to himself on real estate deals. These loans emanated from his position

\footnotetext{
${ }^{17}$ Bunker Hill made the vote a secret ballot when the discount was for a director.
} 
as the sole loan officer in the bank.

\section{Some Statistical Evidence on the Effects of Con- sensus Size}

Although the preceding stories are important and give us impressions about the effects of committees, there is enough data available for the period to perform some simple econometric tests of the predictions from the model. Though the tests are not based on ideal data, there is evidence suggesting that higher consensus levels enhanced the ability to provide a higher return on assets by an economically and statistically significant amount. Banks having a "two votes enough to reject rule" apparently had returns on assets 50 percent higher than banks that did not state their decision process in the byelaws. An extra vote necessary to approve a loan appears to be associated with a two and a half percent increase in the ratio of net profits to total assets.

My econometric sample is for a handful of Boston banks for which I have balance sheet data and governance data. Data on the institutional variables were collected from banks' directors' minutes and bye-laws. Finally, other balance sheet data comes from Weber (1999). ${ }^{18}$ The banks, and the years in which they appear in the sample, are listed in Table 1.

The performance measure I use as a dependent variable is the ratio of net profits to total assets. In my sample the mean of this variable is about 4.2 percent with a standard deviation of 2.6 percent. I use OLS on a pooled sample of Boston banks between 1808 and 1859. I use two measures of institutional arrangements. The first measure of consensus size uses information on the minimum committee size to form a quorum and the voting rule to infer how many votes at a minimum would have been necessary to approve a loan. This proxies for $K$ in the model. This may not be the exact number of votes required on all decisions, but it is the best proxy the sources allow.

\footnotetext{
${ }^{18} \mathrm{I}$ also have balance sheet data and governance data for nine other banks outside of Boston. The heterogeneity of returns across geographic areas complicates estimation however, and I do not include them in the econometric sample.
} 
Table 1: Econometric Sample

\begin{tabular}{cc}
\hline Bank & Year \\
\hline Atlantic Bank & $1829-1861$ \\
BostonBank & $1808-1861$ \\
Massachusetts Bank & $1809-1861$ \\
Shoe andLeather Dealers' Bank & $1837-1861$ \\
StateBank & $1814-1861$ \\
Suffolk & $1826-1861$ \\
Warren/Shaumut & $1837-1861$
\end{tabular}

I coded banks without recorded information on decision rules as a "0", banks with a single decider as "1" and so forth. For example, the Massachusetts Bank in 1821 had a quorum size of five with a majority voting rule yielding a " 3 " for this variable. I also include a control for the number of directors in a bank. This variable determines how much surplus is available to distribute and hence it also influences how the bank would want to organize its decision making procedures.

The second approach is to use an indicator variable for various arrangements. With the data available I can include an indicator for a two votes to reject rule, a majority consent rule and a single decider rule. The omitted category is banks which did not state their decision rule in their bye-laws. Table 2 gives a rough indication of the number of observations and frequencies in my data for each type of rule and for the level of minimum votes.

While the model above has not been parameterized and the functional form is left free, we can get a sense of what an empirical test of that model would look like. Writing net bank profitability, $\Pi$, as a function of exogenous and endogenous variables we have

$$
\Pi(K(N, \alpha, c))=E(\pi \mid K(N, \alpha, c))
$$

This expression says that the expected net profitability of a bank depends exclusively 
Table 2: Frequency of Decision Rules and Minimum Consensus Levels

\begin{tabular}{|c|c|c|c|c|c|}
\hline Rule & Observations & Percent & $\begin{array}{l}\text { Minimum } \\
\text { votes to } \\
\text { approve (k) }\end{array}$ & Observations & Percent \\
\hline Not Stated & 72 & 25.53 & 0 & 72 & 25.53 \\
\hline Single Decider & 56 & 19.86 & 1 & 90 & 31.91 \\
\hline Majority Rule & 64 & 22.7 & 2 & 7 & 2.48 \\
\hline Two To Reject & 74 & 26.24 & 3 & 52 & 18.44 \\
\hline Unanimous consent & 16 & 5.67 & 4 & 6 & 2.13 \\
\hline \multirow[t]{4}{*}{ Total } & 282 & 100 & 9 & 14 & 4.96 \\
\hline & & & 11 & 40 & 14.18 \\
\hline & & & 12 & 1 & 0.35 \\
\hline & & & Total & 282 & 100 \\
\hline
\end{tabular}

on the minimum number of votes necessary to approve a loan. In turn the level of consensus or the number of votes necessary to approve depends on other exogenous variables. While I can control for the number of directors in the bank, information about insider ownership and the opportunity cost of their time is not available. The empirical model simply uses $K$ as a proxy for these unobserved characteristics of the bank. ${ }^{19}$ Additionally, a semi-log linear regression is used to estimate the relationship in (5).

In Table 3 column 1, I present results from a parsimonious OLS regression of the following form

$$
\ln \left(\frac{\text { net profits }}{\text { assets }}\right)_{i t}=\beta_{0}+\text { institutional variable }(\mathrm{s})_{i t}^{\prime} \beta_{1}+\text { time controls }^{\prime} \beta_{2}+\varepsilon_{i t}
$$

where the subscripts are for bank $i$ in year $t$, the institutional variables are as described above, the time controls are a set of unique year indicators and $\varepsilon$ is a disturbance term with the typical assumptions. The following columns present other specifications of the most parsimonious regression model. They are mainly sensitivity checks. ${ }^{20}$

\footnotetext{
${ }^{19}$ If $\alpha$ determines optimal project choice then my estimates of the effect of $K$ are inconsistent since I cannot control for these shares. One possible way to control for this is with bank level fixed effects. I include specifications that do this.

${ }^{20}$ Errors are robust or heteroscedasticity-consistent. Each regression includes year dummies to control for environmental factors affecting all banks.
} 
Table 3: Regressions Based on the Minimum Number of Votes to Approve

\begin{tabular}{|c|c|c|c|c|}
\hline Regressors & 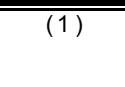 & $(2)$ & $\begin{array}{c}(3) \\
\text { Fixed Effects }\end{array}$ & $\begin{array}{c}(4) \\
R \text { andom } \\
\text { Effects }\end{array}$ \\
\hline $\begin{array}{l}\text { M in im um votes to approve a } \\
\text { loan }(K)\end{array}$ & $\begin{array}{l}0.025 \\
{[0.01]}\end{array}$ & $\begin{array}{l}0.035 \\
{[0.01]}\end{array}$ & $\begin{array}{c}0.16 \\
{[0.09]}\end{array}$ & $\begin{array}{l}0.025 \\
{[0.01]}\end{array}$ \\
\hline D irectors $(N)$ & $\begin{array}{l}-0.024 \\
{[0.008]}\end{array}$ & $\begin{array}{l}-0.034 \\
{[0.008]}\end{array}$ & $\begin{array}{l}-0.05 \\
{[0.25]}\end{array}$ & $\begin{array}{r}-0.024 \\
{[0.01]}\end{array}$ \\
\hline Years in Operation & --- & $\begin{array}{c}-0.001 \\
{\left[\begin{array}{llll}0.0 & 0 & 2\end{array}\right]}\end{array}$ & --- & -- \\
\hline Notes outstanding to capital & --- & $\begin{array}{l}-0.003 \\
{\left[\begin{array}{llll}0.0 & 0 & 3\end{array}\right]}\end{array}$ & -- & --- \\
\hline Constant & $\begin{array}{l}-6.62 \\
{[0.09]}\end{array}$ & $\begin{array}{c}-7.4 \\
{[0.10]}\end{array}$ & $\begin{array}{l}-7.33 \\
{[2.54]}\end{array}$ & $\begin{array}{l}-6.70 \\
{[0.47]}\end{array}$ \\
\hline $\begin{array}{l}\text { Observations } \\
\text { R-squared }\end{array}$ & $\begin{array}{r}233 \\
0.74\end{array}$ & $\begin{array}{r}159 \\
0.83\end{array}$ & $\begin{array}{l}233 \\
0.75\end{array}$ & 233 \\
\hline
\end{tabular}

Column (1) in Table 3 uses the minimum votes that would be necessary to approve a loan and the minimum number of directors to form a quorum as the key explanatory variables. Results in column (1) of Table 3 which correspond to the above regression are supportive of the conclusion that adding an extra vote to approve a loan could add about two and half percent to the return on assets. Starting from the mean return on assets, the model predicts an increase in the dependent variable of slightly larger than half a percentage point if the number of votes necessary to approve moved from not being stated to five which is roughly what a two votes to reject rule would mean in the sample.

Columns (2), (3) and (4) re-run the regression from the previous column but also include other control variables or modify the regression specification. Column (2) adds the ratio of notes in circulation to the capital stock and the number of years the bank had been in operation. The results from the previous column are supported, and the coefficient on the voting variable is larger. Columns (3) and (4) are panel data specifications. Including bank level indicators or "fixed effects" also qualitatively supports the results from column (1), but the coefficient on the minimum number of votes is larger while the number of directors variable is no longer statistically significant. The latter could be explained by the fact there is so little within bank regime change over time. I use a "random 
effects" model in column (4) which allows for a bank specific error term. This estimator may be more efficient but is inconsistent if the institutional variables are correlated with un-observable characteristics of the bank that also affect observed profitability. This regression reveals results very similar to the first specification. ${ }^{21}$ It is tempting to argue that column (1) gives a good indication of the correlation between voting rules and returns, but since there are any number of omitted bank level characteristics it is difficult to make a solid conclusion based on this evidence alone. ${ }^{22}$ Taken together with the historical examples and the theoretical exploration however there is a case to be made for the idea that the level of consensus matters.

Table 4 repeats the specifications of Table 3 but substitutes a set of indicator variables for the minimum votes measure and the minimum directors measure. Again the regressions report a higher return on assets for a larger consensus rule. Compared to banks that did not state their loan decision mechanism, banks with a two votes to reject rule have returns that are higher by slightly more than 55 percent. Starting from the mean, this would imply an improvement of about two percentage points on the return. The coefficient on majority voting is 0.23 - smaller than the "two to reject rule" — which the theoretical model would predict if the number of directors were held constant. However, the data are too noisy to statistically distinguish between a majority voting rule and a single decider rule. ${ }^{23}$

Including other control variables changes the signs of the indicator coefficients for majority rule and the single decider. I conjecture that this is because of collinearity between the rules and how long the banks had been in operation. Also the sign and the magnitude of the coefficient on years in operation is opposite from that in column (2) of Table 3. The results when I include bank specific control terms suggest that a two to reject rule raises returns by an unbelievably large amount and the single decider does

\footnotetext{
${ }^{21}$ A Hausman test for correlation between the regressors and the bank-specific error terms cannot be implemented because the data do not meet the asymptotic criteria of the test.

${ }^{22}$ Correcting for first-order autocorrelation of the error terms does not alter the qualitative conclusions from column (1) of Table 3. In fact the coefficient on the minimum votes variable increases to 0.03 with a standard error of 0.01 .

${ }^{23}$ The null hypothesis of equality of the two coefficients is rejected.
} 
Table 4: Regressions Based on Decision Rules

\begin{tabular}{|c|c|c|c|c|}
\hline Regressors & (1) & (2) & Fixed ${ }^{(3)}$ ffects & $\begin{array}{c}(4) \\
R \text { and om } \\
\text { Effects }\end{array}$ \\
\hline \multirow{2}{*}{ Two to Reject } & 0.46 & 0.4 & 4.52 & 0.46 \\
\hline & {$\left[\begin{array}{lll}0 & .1 & 0\end{array}\right]$} & {$[0.09]$} & {$[0.71]$} & {$[0.11]$} \\
\hline \multirow[t]{2}{*}{$\mathrm{M}$ ajority $\mathrm{R}$ ule } & 0.23 & -0.35 & 0.52 & 0.23 \\
\hline & {$[0.13]$} & [0.29] & [0.5 5] & {$\left[\begin{array}{lll}0 & .1 & 2\end{array}\right]$} \\
\hline \multirow[t]{2}{*}{ S ingle $D$ ecider } & 0.18 & -0.46 & 0.89 & 0.18 \\
\hline & {$[0.09]$} & {$[0.17]$} & {$[0.54]$} & {$\left[\begin{array}{lll}0 & .1 & 2\end{array}\right]$} \\
\hline \multirow[t]{2}{*}{ Years in Operation } & - - & 0.009 & -.- & - - \\
\hline & & {$\left[\begin{array}{lllll}0 & .0 & 0 & 4\end{array}\right]$} & & \\
\hline \multirow[t]{2}{*}{ Notes outstanding to capital } & -- & -0.002 & -- & -- \\
\hline & & {$\left[\begin{array}{lllll}0 & .0 & 0 & 3\end{array}\right]$} & & \\
\hline \multirow[t]{2}{*}{ Constant } & -7.07 & -5.14 & -11.2 & -5.32 \\
\hline & {$[0.13]$} & {$[0.16]$} & {$[0.64]$} & {$[0.45]$} \\
\hline Observations & 233 & 159 & 233 & 233 \\
\hline R-squared & 0.75 & 0.85 & 0.81 & \\
\hline
\end{tabular}

Robust (W hite-Huber) standard errors in brackets; Time dum mies are not reported. Dependent

variable is the log of net profits to as sets.

roughly equally as well as a simple majority rule. The latter two still have a positive correlation however. The results from the random effects specification are similar to those in column (1), and, again, the Hausman test criteria are not satisfied. ${ }^{24}$

The statistical work along with the theoretical and anecdotal evidence points out that consensus mattered. These results are suggestive of the following story: when banks increased consensus size, banks made better loans and their profits were larger for a fixed amount of assets.

\section{Other Controls and Mechanisms}

Discount committees and their decision rules were not the only types of mechanisms that banks used to maintain the integrity of their business. Banks went to great lengths to lend the appearance of having set up mechanisms that would prevent outright theft, favoritism and over-extension of loans to directors. Explicit controls included bonding,

\footnotetext{
${ }^{24}$ Un-reported regressions use the ratio of dividend payouts to the par value of the stock to measure the success of the banking enterprise. While this measure is less than ideal because of the difficulty of analyzing dividend policy in general, one might argue that these measures may capture something about the success of banks in early nineteenth century Boston. Doing so shows a positive and statistically significant relationship between the dividend ratio and the consensus measures. Other informative performance measures such as bank failure rates or information about the outcome of specific loans is unfortunatley not available.
} 
limits on loan amounts to directors, high taxes in the contingency of inconvertibility of issued notes, and collateral-based loans. While these mechanisms were intended to maintain good lending practices, few of these controls could have worked as claimed.

Many of the controls besides discount committee rules were designed to limit directors' abuse of the banks and were quite common across banks of the era. For instance nearly all bank cashiers and sometimes even the directors were bonded under the surety of two signatures. The bonds threatened to exact quite a toll. They were often in the range of $\$ 10,000$ to $\$ 50,000$ (at the very least a multiple of five of an average annual salary) for cashiers and slightly less for others. However the bonds did not and could not cure fraud in the banking system. The Massachusetts Bank Commissioner's report of 1835 found that many of the bonds were incompletely paid or they turned out to be in control of either the bonded himself or the agents guaranteeing the bond.

Limits on directors' loans were also enacted especially after the panic of 1837 . This banking crisis was thought to have stemmed in part from excessive lending to insiders and directors which left the banks open to convertibility problems and possible insolvency. From that time forward, regulators in Massachusetts and other states limited insider lending to varying percentages of the total amount loaned or to a certain proportion of capital. An alternative solution was to limit the amount of loans to directors in relation to capital. Such a resolution theoretically confined the bank, but the limit was flexible and it could be extended in the future if directors or stockholders chose. Such a rule might have fomented an attempt to take the lowest quality loans first in hopes to make up in returns what might be lost in quantity (e.g., a series of low-risk low-return projects).

At the National City Bank in Lynn, Massachusetts in 1858, the stockholders, at the behest of the vice-president, passed a rule limiting loans to each director at $\$ 16,000$ and a total to all directors of $\$ 60,000$ (National City Bank of Lynn (1904)). These rules were not self-enforcing. The next year the total limit was raised to $\$ 70,000$, and in the next year, each director was granted a limit of $\$ 20,000$ while the ceiling for all directors' loans was raised to $\$ 100,000$. At the Bank of Philadelphia, directors were supposed to have 
limited loans to associated businesses and directors. Later it was discovered that the bank had surreptitiously suspended the rules so as to make loans beyond the specified limit to a closely related insurance company. Such perfidy was not rare due to the fact that such rules and limits were neither credible, nor self-enforcing as the discount committee voting rules might have been.

Banks also established ex ante incentives to safeguard the convertibility of their notes. In Massachusetts, banks were to pay a tax of 24 percent on notes outstanding during the time a bank was not convertible. Conant (1927) notes that in the case of widespread abuses in the years running up to 1837 this rule was completely unenforceable. Were the state to charge the toll in the face of a general suspension of payments, the entire banking system would have been jeopardized. ${ }^{25}$ In fact this tax was not totally enforced after the panic of 1837 in Massachusetts. Many banks had exemptions. In the end, such a rule could not prevent general imprudence in the banking industry because ex post it was not credible to enforce.

Keeping contingent funds on hand for surprise demands for convertibility was also difficult to maintain as a safety mechanism. The Bank of Philadelphia was supposed to have such funds available at all times according to its statutes. However in one case it dipped into these funds to pay out a four percent dividend that it otherwise could not have paid; this custom was not foreign to banks of the time. Obviously repeated action like this would lead to irreparable damage to the safety fund. Still other banks attempted to maintain the integrity of their loans by requiring collateral or at least two co-signers for loans. Such mechanisms, common to current practices in banking, probably were complementary to the other mechanisms described above, but they were not ubiquitous in the early nineteenth century.

Overall the limits and controls that assured high quality decision making and prudent insider lending had to be self-enforcing in nature otherwise they were ineffective. Banks devised and used many controls and mechanisms to help them make such decisions and

\footnotetext{
${ }^{25}$ This situation reminded Conant of what Cicero said: "I can see no danger to which you are personally exposed, separately and apart from the destruction of us all."
} 
to prevent problems, but the most effective controls appear to have been discount committees with adequate levels of consensus and the reputation of local bankers for making good decisions.

\section{Conclusions}

This paper has analyzed the internal decision making processes of banks in the northeastern region of the US between 1784 to 1864 . The primary source of information on the decision making procedures for the banks comes from their bye-laws. Some of these stipulated mechanisms for the banks that may have ensured prudent, high-quality lending. Although no direct evidence is available, simple econometric tests and the anecdotal evidence are consistent with the predictions of the theoretical model.

High-consensus committees acted in sync with the desire to maintain previously established reputations to produce a more efficient capital market for early nineteenth century New England. Insider lending or connected lending is thus more viable when institutions mitigate the informational and incentive problems inherent to such a transaction.

Modern economies, especially those blamed for the international financial chaos of late, may learn something from past behavior by establishing, innovating and experimenting with institutions that maintain the integrity of transactions. Of course an important aspect of the story that deserves more research is the role played by the directors' direct ownership of the banks.

In any case, the evidence gathered here highlights the fact that institutions mattered for enabling the process of growth in the early years of the United States of America. To the extent that this emanates from the mobilization of capital, such mechanisms also promoted increases in productivity in the nineteenth century. 


\section{References}

Atlantic Bank Directors' Minutes. Bank of Boston Archives.

Beveridge, A. A. (1985): "Local Lending Practice: Borrowers in a Small Northeastern Industrial City, 1832-1915," Journal of Economic History, 45(2), 393-403.

Boston Bank Directors' Records. Baker Library, MSS. 781 1803-1818.

Bunker Hill Bank Directors' Minutes. Baker Library, MSS. 781.

Conant, C. A. (1927): History of Modern Banks of Issue. G.P. Putnam's Sons, New York.

An Act to Incorporate the President, Directors, and company of the Dedham Bank: Together with the Bye-Laws of Said Corporation Baker Library.

A Defence of the Country Banks Being a Reply to a Pamphlet Entitled An Examination of the Banking system of Massachusetts in Reference to The Renewal of the Bank Charters.

Faulkner, W. (1833): Merchant's Bank: Connecticut Act to Incorporate the Merchants' Bank Norwich City. Norwich, Conn.

Felt, J. B. (1839): An Historical Account of the Massachusetts Currency. Perkins and Marvin, Boston.

Gras, N. (1937): The Massachusetts First National Bank of Boston 1784-1934. Harvard Univeristy Press, Cambridge, MA.

Hammond, B. (1957): Banks and Politics in America from the Revolution to the Civil War. Princeton University Press, Princeton, NJ.

The Hartford National Bank (1901): The Hartford National Bank, 1792-1901. Hartford, Conn.

Knox, J. J. (1900): A History of Banking in the United States. Bradford Rhodes and Company, New York.

Lamoreaux, N. (1994): Insider Lending: Banks, Commercial Lending and Economic Development in Industrial New England. Cambridge University Press, New York.

Massachusetts Bank Commissioner (various issues): Abstract Exhibiting the Condition of the Banks in Massachusetts. Boston.

National City Bank of Lynn (1904): Semi-centennial of the National city bank of Lynn, Massachusetts, October 1, 1904. The Nichols Press, Lynn, Mass.

Plymouth Bank Records, 1803-1875. Baker Library, Mss: 781 1803-1875.

Shoe and Leather Dealers' Bank Directors' Minutes. Bank of Boston Archives.

The Suffolk Bank Collection. Baker Library, Mss: 781 1818-1904.

Sutton Bank Discount Records. Baker Library, Mss: 781 Folder 9. 
Various Authors (1896): History of Banking in all the Leading Nations. Journal of Commerce and Commercial Bulletin, New York.

Weber, W. E. (1999): Balance Sheets for U.S. Antebellum State Banks. Research Department Federal Reserve Bank of Minneapolis 
We want to show that if a project, $\pi$, is proposed that a bribe equal to $\alpha[\phi(1)-\pi \phi(\pi)]$ will make a voter indifferent between approving and not approving. Hence the project will be implementable as a Nash equilibrium.

At this stage the directors participate in the voting mechanism $\Gamma=\left\{S_{1}, \ldots, S_{N}, g(\cdot)\right\}$. Where the vector $S=\left(S_{1}, \ldots, S_{N}\right)$ is a collection of $N$ strategy sets and $g$ is an outcome function $g: S_{1} \times \cdots \times S_{N} \rightarrow X$. $X$ is 0 if the project, $\pi$, is not approved or 1 if it is approved. The strategy set for any director $n$ is $\{0,1\} ; s_{n}=1$ if a director approves and $s_{n}=0$ if he rejects. The mechanism $\Gamma$ is a simultaneous-move voting game with secret ballots offering a project $\pi$ for approval or disapproval. Side payments can be offered which 'buy' votes. The proposer can credibly commit to paying them contingent upon the approval of the loan. A consensus $K$ of the $N$ directors on the loan committee is necessary for approval. Thus a project gets approved if $\sum_{n=1}^{N} s_{n} \geq K$.

Lemma 1: There is a level of consensus $\widetilde{K}$, such that $\pi$ is implementable in Nash equilibrium when bribes for each of $\widetilde{K}-1$ directors are equal to $\alpha[\phi(1)-\pi \phi(\pi)]$.

Proof: Let us assume that the bribing director's rationality constraint is not biding. Then note that the director up for a loan will always want to approve the loan. Those not bribed have a weakly dominant strategy of not approving because of the following logic.

First, a given director might reckon that enough directors have approved the project so that it would be implemented. In this case the director could disapprove and have the same expected utility as that gained by approving: $\alpha[\pi \phi(\pi)]$. We can use the previous argument inductively for all other directors who are not bribed and assume that players' indifference gives rise to them not approving. This indifference argument is a standard assumption in the literature on implementation in weakly dominated strategies.

The second case is when the director reckons $\widetilde{K}-2$ or fewer directors have approved the project. In this case the director's utility is $\alpha[\phi(1)]$ no matter how he votes. The final case is when $\widetilde{K}-1$ directors have approved. By approving, the director would have a payoff of $\alpha[\pi \phi(\pi)]$ and by disapproving the director would have a higher payoff of $\alpha[\phi(1)]$. Consequently disapproving weakly dominates approving. This reasoning highlights the fact that without transfers no project except $\pi=1$ can be implemented in weakly dominant strategies except when $\widetilde{K}=1$.

Now consider the directors that are "approached" for a bribe. There will be a Nash equilibrium where bribed directors approve if

$$
E\left[U_{n}\left(\text { approve }, \tau_{n}, s_{-j}\right)\right]=\alpha[\pi \phi(\pi)]+\tau_{n} \geq E\left[U_{n}\left(\text { disapprove }, \tau_{n}, s_{-j}\right)\right]
$$

for all possible $s_{-j} \in S_{-j}$.

The director up for a loan will approve his own loan, and therefore only has to find $\widetilde{K}$ -1 directors to approve. Since all other directors essentially have the same reservation utility when not taking a project we assume that the transfers will be equal. It is easy to see that if $\tau_{n}=\alpha[\phi(1)-\pi \phi(\pi)]$, and the director approves, the bribed director will have the same expected utility regardless of any other strategy played by the others. 


\section{Appendix B}

Detailed Governance Data for Northeastern Banks, 1782 - 1861

\begin{tabular}{|c|c|c|c|c|c|c|}
\hline State & Bank Name & $\begin{array}{c}\text { Year of } \\
\text { Observation }\end{array}$ & $\begin{array}{l}\text { Number of } \\
\text { Directors }\end{array}$ & $\begin{array}{c}\text { Minimum } \\
\text { Committee Size }\end{array}$ & $\begin{array}{c}\text { Number of votes } \\
\text { to reject } \\
\text { a discount }\end{array}$ & $\begin{array}{c}\text { Number of votes } \\
\text { to accept } \\
\text { a discount }\end{array}$ \\
\hline \multirow[t]{19}{*}{ MASSACHUSETTS } & BOSTON & & & & & \\
\hline & Atlantic Bank & 1828 & 12 & 7 & & 1 \\
\hline & Boston Bank & 1803 & 12 & 4 & 2 & \\
\hline & " " & 1806 & & & & majority \\
\hline & $\begin{array}{l}\text { Massachusetts } \\
\text { Bank }\end{array}$ & 1782 & 12 & & 1 & \\
\hline & " " & 1786 & 9 & & 1 & \\
\hline & " " & 1811 & 9 & 5 & 2 & \\
\hline & " " & 1821 & 9 & 5 & & majority \\
\hline & " " & 1825 & 9 & 3 & & majority \\
\hline & " " " " & $\begin{array}{l}1831 \\
1840\end{array}$ & $\begin{array}{l}9 \\
9\end{array}$ & $\begin{array}{l}2 \\
1\end{array}$ & & $\underset{1}{\text { majority }}$ \\
\hline & Middling Interest & 1836 & 12 & & not stated & \\
\hline & " " & 1837 & 9 & & not stated & \\
\hline & " " & 1840 & 5 & & not stated & \\
\hline & Shawmut(W arren) & 1836 & 12 & & not stated & \\
\hline & $\begin{array}{l}\text { Shoe and Leather } \\
\text { Dealer's Bank }\end{array}$ & 1851 & & 1 & 2 & \\
\hline & Suffolk Bank & 1818 & 12 & 5 & 2 & \\
\hline & " " & 1851 & 12 & 5 & 2 & \\
\hline & " " & 1856 & 12 & 5 & 2 & \\
\hline & State & 1811 & 12 & 7 & not stated & \\
\hline \multirow[t]{8}{*}{ MASSACHUSETTS } & NOT BOSTON & & & & & \\
\hline & $\begin{array}{l}\text { Merchant's } \\
\text { (Salem) } \\
\text { Merchant's } \\
\text { (New Bedford) }\end{array}$ & $\begin{array}{l}1811 \\
1825\end{array}$ & $\begin{array}{l}9 \\
8\end{array}$ & 3 & $\begin{array}{l}\text { not stated } \\
\text { not stated }\end{array}$ & \\
\hline & Southbridge & 1836 & 12 & 3 & 1 & \\
\hline & Worcester & 1804 & 7 & & not stated & \\
\hline & Plymouth & 1803 & 7 & & not stated & \\
\hline & City/Lynn & 1858 & & & not stated & \\
\hline & Dedham & 1815 & 12 & 7 & & 1 \\
\hline & Bunker Hill & 1826 & & 4 & 2 & \\
\hline \multicolumn{7}{|l|}{ MAINE } \\
\hline & Portland & 1838 & 7 & 4 & & majority \\
\hline \multicolumn{7}{|l|}{ CONNECTICUT } \\
\hline & Phoenix & 1814 & 11 & 3 & not stated & \\
\hline & Merchant's & 1833 & 9 & 3 & not stated & \\
\hline & Hartford & 1792 & & & 2 & \\
\hline & Stamford & 1834 & 9 & & not stated & \\
\hline \multicolumn{7}{|l|}{ PENNSYLVANIA } \\
\hline & B. of N. America & 1814 & 12 & 5 & & $\begin{array}{l}\text { President } \\
\text { decides }\end{array}$ \\
\hline & Philadelphia & 1803 & 16 & & not stated & \\
\hline \multicolumn{7}{|l|}{ NEW YORK } \\
\hline & $\begin{array}{l}\text { North American } \\
\text { Trust \& Banking }\end{array}$ & 1838 & 7 & 7 & 2 & \\
\hline & Bank of NY & 1784 & 13 & 7 & & majority \\
\hline
\end{tabular}

